炭素材料のなかのナノカーボン

\author{
稲垣道夫*
}

(平成14年7月12日受理, 平成14年7月17日採択)

\title{
Nanocarbons in Carbon Materials
}

\author{
Michio Inagaki*
}

Development of carbon materials was divided into three periods ; down to 1960 classic carbons were mostly studied and produced, in 1960-1985 various new carbon materials were developed and from 1985 to now fullerenes and carbon nanotubes attracted attentions. Features of each period were discussed. Different classifications of carbon materials, such as graphitizing and non-graphitizing carbons, classic and new carbons, etc., were also summarized. Based on these discussions, it was proposed that a novel classification of carbon materials, that is, nanocarbons, has to consist of not only nano-sized materials, such as fullerenes and carbon nanotubes, but also nano-structured materials, such as well-controlled porous carbons and boron-doped carbons.

KEYWORDS : Classic carbons, New carbons, Nano-sized, Nano-structured

\section{1.はじめに}

1985年11月に炭素原子60個からなるクラスターの生成と その構造が報告されて以来, 炭素材料の動きはまことに目ま ぐるしく, いろいろな意味で時代が変わったといっても過言 ではない。炭素材料にとっての変革期は, それ以前にも何回 かあったであろう。ガラス状カーボン, 熱分解炭素そして炭 素繊維 (PAN系) の開発がなされた1960年代始めが, それに当 たると考えられる。そこで,ここでは1960年以前を第I期, 1960年から1985年までを第II期，そして1985年以降を第III期 と呼ぶこととした。Table 1にそれぞれの期間に開発された 炭素材料とその期間の特記すべき事項を簡潔にまとめた。
この分類によれば, 現在は第III期にあって最も変動の激し い時期に感じられる。炭素材料の新しい, そして目覚ましい 展開を我々は身をもって感じている。このような動きの中で, “ナノカーボン”という言葉が生まれ，使われるようになった。 しかし,その“ナノカーボン”が,どのような炭素材料を指して いるのか, 明確な定義がなされて使われているわけではない。 この言葉は, 信州大学の遠藤守信教授が, 日本学術振興会の 未来開拓学術研究事業に「先進エネルギーデバイス用ナノカ ーボンの基礎科学と応用」を申請したときに始まったとの説 がある。このプロジェクトは1999年に採択され, 現在進行し ていることから,ナノカーボンという言葉も認知されたと受 け止められている。そして, 2001年11月には, 長野市でInter-

Table 1 Carbon periods.

\begin{tabular}{|c|l|l|l|}
\hline Period & Years & Carbon materials developed & \multicolumn{1}{c|}{ Remarks } \\
\hline I & $\sim 1960$ & $\begin{array}{l}\text { Artificial graphite blocks } \\
\text { Activated carbons } \\
\text { Carbon blacks }\end{array}$ & $\begin{array}{l}\text { Mass production } \\
\text { Sale in either tons or kilograms }\end{array}$ \\
\hline II & 1960 & $\begin{array}{l}\text { Various carbon fibers } \\
\text { Glass-like carbons } \\
\text { Pyrolytic carbons } \\
\text { High density isotropic graphites } \\
\text { Intercalation compounds } \\
\text { Various composites } \\
\text { (CFRP, CFRC, etc.) }\end{array}$ & $\begin{array}{l}\text { Introduction of various techniques for the production } \\
\text { of carbon materials (e.g., CVD, composite with other } \\
\text { materials, etc) } \\
\text { Developments of new applications } \\
\text { Sale mostly in grams }\end{array}$ \\
\hline III & $1985 \sim$ & $\begin{array}{l}\text { Fullerenes } \\
\text { Carbon nanotubes }\end{array}$ & $\begin{array}{l}\text { Nano-sized } \\
\text { Sale in milligrams }\end{array}$ \\
\hline
\end{tabular}

Corresponding Author, E-mail: ina@ac.aitech.ac.jp 愛知工業大学：T470-0392 豊田市八草町八千草1247

Aichi Institute of Technology : Yakusa, Toyota 470-0392, Japan 
national Symposium on Nanocarbonsが開催され, 世界各国から 400名以上の参加者が集まった。この国際会議は,ナノカーボ ンに対する世界の研究者の関心がいかに高いかを示したもの とも司える。この国際会議の最後のパネルディスカッション において,筆者が“ナノカーボン”の定義を提案したが,十分考 えて提案したものでもなく，その説明も適切であったとはい えなかったにもかかわらず,たくさんの方々からコメントを いただいた。特に, Journal CARBONのChief Editorsの1人で あるProf. L. A. Radovicからは, 種々の議論とアドバイスをい ただき, 現在その議論をまとめて, 同誌にLetter-to-the-Editor として投稿し, 印刷中である”。

本稿では, 炭素材料を, その開発の過程で, どのように分類 し, 考えてきたかを, 私なりに振り返り,ナノカーボンという 分類が行わ机る現在に至った経過を考察する。そして,ナノ カーボンという言葉を使う正当性と問題点を整理してみた い。なお, 本文中での炭素材料の名称は開発された当時のも のではなく, 現在の名称を使用した。例えば, 開発当時は熱分 解黒鉛 (Pyrolytic graphite) と呼ばれていたものは, その後の 研究から黒鉛構造が生成している訳ではないことが明らかに なり, 熱分解炭素 (Pyrolytic carbon) と呼ばれている。

\section{2. 炭素材料第 | 期}

第I期は, 西暦前から1960年代までの長期間にわたってい る。この期間中にも多くのエポックがあり, 時代を画すよう
な出来事があったに違いない。例えば, 天然黒鉛を使って鉛 筆がイギリスで開発されたとき (1575年) には, その簡便さは 画期的と思われたに違いない。天然黒鉛がダイヤモンドと同 じ炭素原子からできていることがわかったとき(1772年) は， きっと多くの人が真っ黒な黒鉛やコークスと透明で貴重なダ イヤモンドが同じ元素からできているとは信じられなかった であろう。石炭タールからコークスの製造が可能となったと き (18世紀初頭)，そしてそのコークスを使って人造黒鉛電極 が製造されるようになったとき(19世紀初頭) は，それぞれが その時代の新しい局面を切り拓いたという意味に扔いて， 人々の注目を惹いたと考えられる。黒鉛電極はその後の鉄の 時代ともいわれる19世紀の土台骨であったとも言えよう。

この第I期で開発された炭素材料は, 人造黒鉛電極で代表さ れる人造黑鉛類, カーボンブラック類そして木質原料などか ら作られた活性炭類である。この3種の炭素材料は現在でも 重要な工業材料であり, 大量に生産されている。この3種の炭 素材料を筆者は, 次の第I期で開発され“ニューカーボン”と 呼ばれるものと対比する意味で, “クラシックカーボン”と呼 ぶことを提案したい。「クラシック」とは決して古いことを意 味する言葉ではなく, むしろ最高級あるいは代表的であるこ とを意味する言葉である。ニューカーボン材料との対比のみ でなく, 現在も大量に生産され, 広い範囲で使われ, 依然とし て炭素材料を代表するものであることをも表している。そし て, 人造黒鉛, カーボンブラックそして活性炭の生成が基本的

Table 2 Controlling factors for the production of various carbon materials and the key points for their nanostructure.

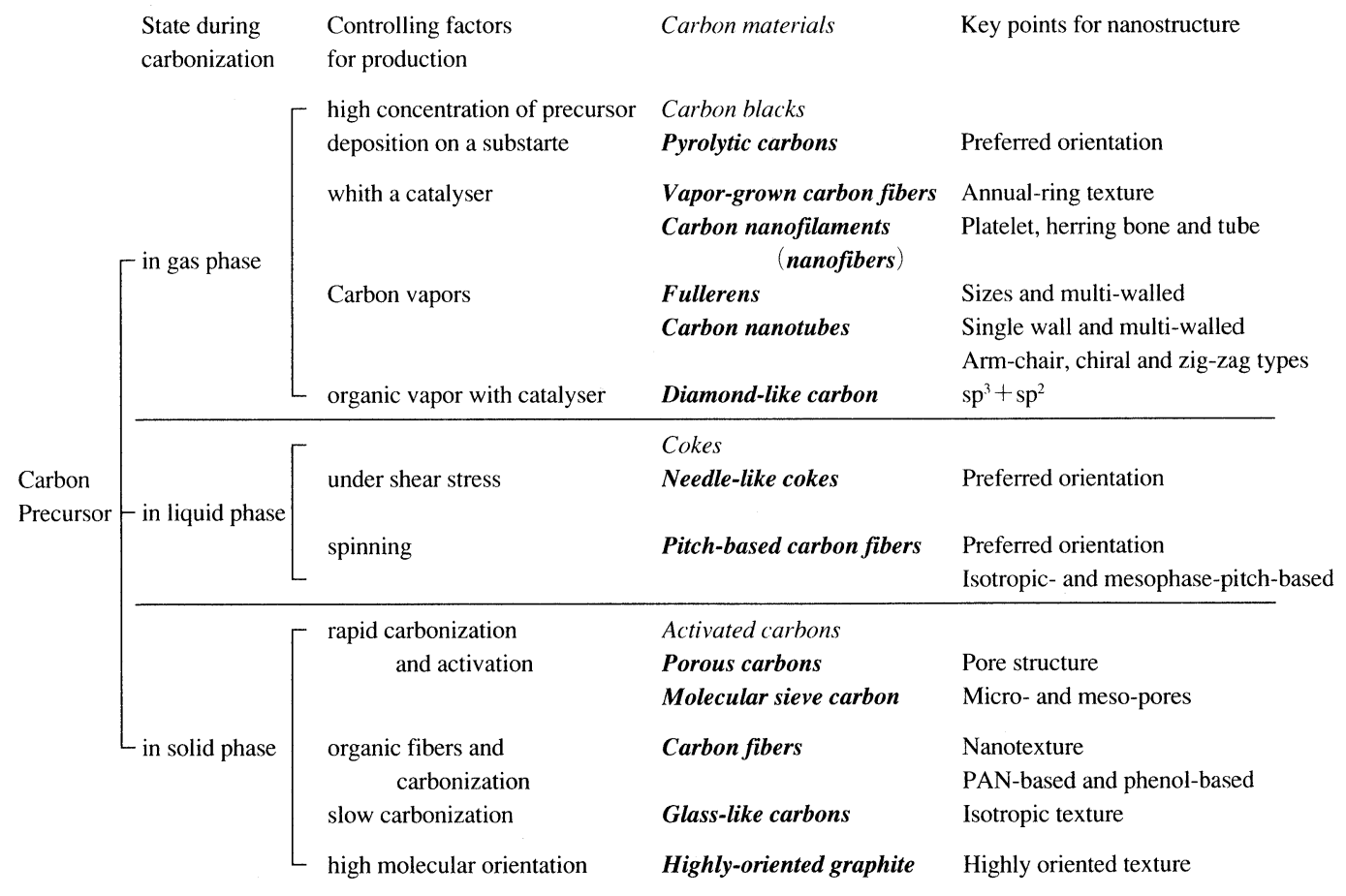


にそれぞれ液相, 気相そして固相で起こっている。したがっ て, 3つの炭素材料の生成プロセスを代表する炭素材料とも言 えよう(Table 2参照)。

これら 3 種のクラシックカーボン材料の生産は, もっぱら大 量生産の実現や製品の大型化に努力が集中していたように思 われる。また, 生産量や販売量が大きな単位, すなわちトンや キログラムで示されることが多かった。当時の「重厚長大」の 思想を反映していたとも言えよう。

\section{3. 炭素材料第II期}

この時期は, 炭素材料の製造に新しい手法が取り入れられ るとともに, ほかの材料との組み合わせ (複合化)によって,ク ラシックカーボンとは違った性質や外見をもった炭素材料が 開発されたことであろう。この第I期は前述のように, ポリア クリロニトリル系炭素㵶維, 熱分解炭素およびガラス状炭素 の開発によって始まった2!。

ポリアクリロニトリル繊維を酸化することによって不融化 し, その後炭素化することによって炭素繊維が開発された。 炭素繊維の細い束で自動車をつり上げることによって, その 強さを強調した写真が頻繁に示された。炭素材料製造に酸素 の存在はタブーと考えられていたそれまでの常識を覆したこ と, 炭素繊維の柔軟さと強さは, クラシックカーボンとはかけ 離れたものと思われた。このPAN系炭素繊維の開発直前に, レーヨンを原料とした炭素繊維 (レーヨン系炭素纎維) も開発 されたが, 炭素繊維としての性質の優秀さからPAN系炭素緎 維の工業化が急速に進んだ。

ほぼ同時期に, 熱分解炭素がいわゆる化学蒸着法 (CVD法) によって作られた。これは炭素網面が高度に配向しており， 強い異方性をもっていることが特徴であった。薄い熱分解炭 素の板を下からバーナーで熱すると, 板を挟んで直上にある 鉛の兵隊は溶けないのに, 離れた位置にある板の端に立って いる鉛の兵隊が溶けているデモンストレーションが印象的で あった。その後の研究は, その製造条件を選択することによ って, 高い異方性をもつものから異方性のないものまで, その 構造を制御できることが明らかとなった。そして, その製造 技術は, 原子炉燃料の炭素被覆に利用されるとともに, 心蔵弁 などの生体用炭素材料の開発につなげられた。

これに対して, ガスをまったく通さない炭素材料, ガラス状 炭素の開発も我々を驚かせた。密度が低いにもかかわらずガ ス不透過性であり, しかも, 方向によって性質がほとんど変わ らない等方性であることも, 炭素材料の構造の基本をなす結 晶子が本質的に異方性をもつことから見て, 驚きであった。 それは, 機械的には脆く, その破面は鋭いエッジがたっており， シリカなどを主成分とする無機ガラスの破面と同様な貝殸状 の模様を示すことから,この名前が付けられたことを聞き, 透 明ではないのにガラス状と呼ぶことを納得したことを記憶し ている。
これら3種の炭素材料は, 第I期でのクラシックカーボンか らは考えられない構造や性質をもっており, 炭素材料にとっ ての新しい時代の開始にふさわしいものであった。そして, その後ぞくぞくと新しい炭素材料が開発された。

1964年に我が国で初めて炭素材料に関する国際会議 (Inter-

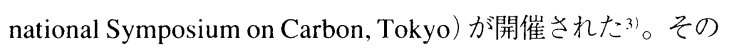
折りに, 溶融ピッチ中に球状の異方性体が生成していること が, カラームービーで示され, 大きな衝撃を感じた。そのとき 運悪く東京が停電で, 冷房のまったく効かない蒸し暑い会場 で汗を流しながら, 真っ暗にしてムービーを見たことも, より 記憶を鮮やかにしている。この液晶の1種としてのメソフェ ーズの研究は, ニードルコークスの開発につながり, 製鋼炉の 超高電力操業を支えた。また, 球状のメソフェーズを単離し たメソカーボン・マイクロビーズの開発・利用につながっ た。さらに, メソフェーズを主成分とするピッチを紡系, 炭素 化することによる炭素繊維 (メソフェーズピッチ系炭素繊維) の開発は, 炭素繊維の弾性率の向上に寄与するものとして大 きな期待を集めた。メソフェーズピッチ系炭素繊維の開発に は, 等方性のピッチを原料とする炭素繊維の製造技術の開発 も重要な役割を担った。

PAN系およびピッチ系炭素繊維が有機前駆体の紡系, 不融 化, 炭素化を経て作られるのに対して, 化学蒸着法と微粒子鉄 触媒を組み合わせることによる炭素繊維の製造技術も開発さ れ, 気相成長炭素繊維と名付けられた。有機前駆体を用いた 炭素㵶維が無限に長い繊維を製造できるのに対して, 気相成 長炭素繊維は短繊維しかできない。しかし, 気相成長炭素緎 維はその断面で年輪状組織をもつとともに繊維軸に沿って高 い配向度をもつこと, そのために高温処理によって黒鉛構造 が発達し得ることが特徵となっている。この繊維の開発初期 にすでに, 触媒微粒子を先端にもった細い中空のチューブが いったん生成し, その表面に熱分解によって炭素が蒸着して いることが明らかにされていた4)。その中空チューブこそが, 現在カーボンナノチューブと呼ばれているものであった。

クラシックカーボンの1つである人造黒鉛の製造技術，すな わちフィラーコークスをバインダーピッチで成形, 炭素化, 黒 鉛化する技術を改良し, 高密度・等方性黒鉛材料が開発され た。その要点は, フィラーコークスに微粒子を用い, 液体を媒 体とする静水圧プレス成形することにあり, 高温でのハロゲ ンガスによる高純度化処理技術の確立とあいまって, 原子炉 用黒鉛材料としての要件を満足し得るようになった。この高 密度 ·等方性炭素材料は, 放電加工用電極, 半導体製造用治具 などの多くの用途をもたらした。

また, 炭素材料とほかの材料との複合化による新材料の開 発も多くの成果を収めた。炭素繊維をフィラーとした炭素䋐 維強化複合材は, 樹脂をマトリックスとすることによって, 航 空・宇宙用からラケット, 釣り竿などのスポーツ用品にまで 広く使われるようになった。さらに, セメントとの複合材も 
大きな成功を収めた。現在, 炭素繊維束およびそのプラスチ ックスとの複合材が, コンクリート橋脚や煙突の補強に, 頻繁 に使われている。黑鉛層間にAsF 5 などをインターカレーショ ンさせることによって, 金属銅よりも高い電䜪伝導度が得ら れるとの報告は急速に世界に広まり，黑鉛層間化合物研究の ブームを惹き起こした。これは実用化に結びつかなかったが, 現在ではリチウムのインターカレーション・デインターカレ ーションを電極反応として利用した, リチウムイオン二次電 池が広く使われている。

これらの材料は, クラシックカーボンとは大きく異なって おり,広く二ューカーボンと呼ばれた。我が国でも, 二ューカ 一ボン研究会 (後にニューカーボンフォーラム) を発是させ, 炭素を製造している企業のみでなく, それを利用している企 業も一緒になって, 研究, 討論する機運が生まれた。

また,これらのニューカーボンの多くはグラム単位で製造, 取り引きされるもので, 第I期でのトンあるいはキログラム単 位で製造, 取り引きしていたクラシックカーボンとは, 意識の 上でも変勒必要であった。そのことはまた, 第I期での大量 生産を目指寸技術開発から, 第II期での高品質, 高付加価値の 炭素材料を開発, 製造するための技術開発への変換が必要と されるようになった。

以前の「重厚長大」の思想に対して,「軽薄短小」の思想を反 映していたとも言える。

\section{4. 炭素材料第 III 期}

1985年のバックミンスターフラーレン $\mathrm{C}_{610}$ の発見は, 炭素材 料の構造に革命をもたらしたといっても過言ではない。それ 以前にすでに, 炭素一炭素結合の3 種の混成軌道, すなわち $\mathrm{sp}^{3}$, $\mathrm{sp}^{2}$ そて $\mathrm{sp}$ 混成軌道に対応して, ダイヤモンド, グラファイト そしてカルビンが存在していることが指摘され, $\mathrm{sp}^{2}$ 混成軌道 では炭素原子が六角網平面を形成するしかあり得ないと考え られていた。しかし,フラーレンの発見は, $\mathrm{sp}^{2}$ 混成軌道によっ て五員環が生成し, 六員環と共存し球殼状のクラスターを作 ることを示した。そして, そのクラスターは分子として挙動 することは, それまでの炭素材料を含めた無機化合物の常識 (すなわち, 分子は存在しない) をまったく覆すこととなった。 フラーレンは $\mathrm{C}_{60}$ にとどまらず $\mathrm{C}_{70}$ から $\mathrm{C}_{240}, \mathrm{C}_{540}$ と巨大なもの も存在し得ること, そして炭素層が幾重にもなったマルチフ ラーレンも存在することが明らかとなった。その後の全世界 的な研究の広がりは, 多くの成果を収めたが, 他方ではそれま で作られてきたカーボンブラック粒子と同じではないかと思 われるものまでフラーレンと呼んで発表する論文も見受けら れた。

1991年のカーボンナノチューブの発見は, さらに炭素材料 の常識を変えることとなった。六角網面は平面しか作り得な いと考えられてきたものが, 直径約 $1 \mathrm{~nm}$ という細さのチュー ブとなり得ることを示した。そして，そのチューブの軸に対
する六員環の相対的な们きによって,物性が金属的になった り半導体的になると予想され，興味深い物性が期待されてい る。また, 単層ナノチューブから多層ナノチューブも存在し 得る。

これらの炭素材料の発見とその物性面での魅力は, 同時期 に注目されていたナノテクノロジーに大きなインパクトをよ え, 現在ではナノテクノロジーを具現するための最も重要な 材料の1つと考えられ，世界的な研究の広がりを見せている。

カーボンナノチューブに注目と期待が集まるとともに, そ れを大量に合成することを目的として, 炭化水素ガス類の気 相における熱分解など種々の手法が使われた。しかし，そこ で合成されたものの多くは小さな網面がチューブ軸に平行に 配向して蒸着した構造をもっており, 前期 (第II期) で開発さ れた気相成長炭素㵶維あるいは纎維状蒸着炭素 (fibrous deposited carbons）と変わらないにもかかわらず,ナノチュー ブという票葉が使われた。それらのあるものは $3000^{\circ} \mathrm{C}$ 付近の 高温への加熱処理によって平坦な網面となり, よりナノチュ ーブに近いものとなるものもある。しかし, そのような構造 変化はすでに気相成長炭素繊維においてよく知られているこ とである。

上記の気相熱分解によって生成する繊維状炭素材料は別の 面からも注目を集め, 多くの研究がなされた。そして, それら はナノファイバー (nanofibers) あるいはナノフィラメント (nanofilaments) と呼ばれた (筆者は後者の呼び方を提唱して いる5!)。これらのナノフィラメントが注目される契機を与え たのは,そのあるものが驚異的に大きな水素貯蔵能を示すと の報告がなされたことにある。残念ながら，その大きな貯蔵 能はいまだにほかの研究グループによって検証されないまま となっている。

\section{5. 炭素材料の分類}

個々の炭素材料の命名にもそれぞれの経緯と理由が隠され ている。例えば, 前記のように透明でもないのになぜガラス 状炭素と呼ばれたかなど。さらに, それら個々の炭素材料を まとめて, 分類し, 総称することも行われてきた。

炭素材料第 $I$ 期に対象となった人造黒鉛では, 黒鉛構造が発 達し得るかどうかが大きな問題であり, その高温での黒鉛化 挙動を支配する因子は何であるかの研究, 議論がなされた。 その過程で, 高温への加熱処理以前の炭素材料を, 高温処理を すれば黒鉛構造が発達し得るかどうかを示すことは重要なこ とであり,易黒鉛化性炭素 (graphitizing carbons, graphitizable carbons) および難黑鉛化性炭素 (non-graphitizing carbons, non-graphitizable carbons) という分類が生まれた(この間の 経緯については, 文献5》を参照されたい)。

第I期にはいると, 前述のように続々と新しい炭素材料が開 発され,それらをニューカーボン (new carbons) と総称するよ うになった。しかし，そのニューカーボンが具体的にどこま 
での炭素材料を含むのかも十分議論されないまま使われた。 最近発刊された「カーボン用語辞典」には「ニューカーボン」 という項目は収録されていない。ニューカーボンと総称され る炭素材料では, ガラス状炭素で示されるように, 必ずしも黒 鉛構造の発達を必要としない用途をもつものも多いことから, 第I期で使われた易黑鉛化性・難黑鉛化性という分類はあま り意味をもたなくなった。また,このニューカーボンとの対 比として「クラシックカーボン」という言葉も必要となった。

第II期に出現したフラーレンあるいはカーボンナノチュー ブ類は, 第II期で出現したニューカーボンよりももっと革新的 であり，その意味で「ニュー」であった。したがって,これらの 材料をニューカーボンの一員と考える立場と, 入れない立場 とに分かれた。この立場の違いは, 研究者および技術者のバ ックグラウンドに依存しているように思える。すなわち, 従 来のクラシックカーボン, ニューカーボンを扱ってきた人々 にとってはフラーレン,ナノチューブもニューカーボンの1つ と考えることが多い。こ机に対して,フラーレンあるいはナ ノチューブを研究対象あるいは商品として扱っている人々の 多くは,ニューカーボンと一線を画そうとする傾向がある。

このような状海の中で,「ナノカーボン」という呼び方が提 案され，注目を集めることとなった。昨年末の長野での国際 会議に 400 人を超す参加者があったことは,この言葉が多くの 人々の共感を呼ぶ要素をもっていることにほかならない。し かし, その会議でも「ナノカーボン」が何を指しているかの共 通の理解が得られたわけでもない。

筆者は, 基本となっている炭素一炭素混成軌道 $\mathrm{sp}, \mathrm{sp}^{2}$ そして $\mathrm{sp}^{3}$ をとに炭素材料をカーボンファミリーとして総括し，そ れぞれの混成軌道をもつ炭素材料をファミリーメンバーとし て捉えることを提唱している。 $\mathrm{sp}$ 混成軌道によるカルビン, $\mathrm{sp}^{2}$ 軌道を基本としたグラファイトおよびフラーレン, そして $\mathrm{sp}^{3}$ 軌道によるダイヤモンドの4つをファミリーメンバーと考 え,それぞれのメンバーがそれぞれ特徵的な多様性をもって いるために, 多種類の炭素材料が生成していると考えている。

一方, ニューカーボン発展の推移をもとに, フラーレンなど の出現と炭素材料に対する社会からの新しいニーズに応える ことを念頭に,「カーボンアロイ」というまったく新しい概念 が提唱された6).77。この言葉は, 文部省 (当時)の科学研究費. 重点領域研究 (当時)への申請に使われたこともあって, その きちんとした定義がなされている。その定義に従えば, 炭素 原子を主体とするが, 他成分と種々のスケールで物理的ある いは化学的相互作用をもって集合体を作っているものを積極 的に炭素材料に包含しようとするものである。異種原子，イ オンを静電相互作用で黑鉛層間に取り込んだインターカレー ション化合物, 炭素原子との置換によって生成するボロン固 溶体, 炭素繊維と同じ炭素の複合材 (炭素一炭素複合材) はも ちろん, 気孔も1つの成分と考えて炭素とのアロイングと考え るものである。

\section{6. ナノカーボン}

フラーレンおよびナノチューブを「ナノカーボン, nanocarbons」という分類に含めることに反対はないであろう。この 場合の「ナノ」はサイズを表していることになる。ナノサイズ であること (nano-sized) は, その炭素材料に新しい特徴さら には機能を与えることになる。例えば,フラーレン,ナノチュ 一ブに限らず, 黑鉛をナノサイズにすることができれば，まっ たく新しい機能が期待できることが理論的に示され，それを 実験的に実証しようとする試みが地道に続けられている8 。

しかし, 炭素材料の用途の急速な広がり，そして大きな期待 を考えると, サイズがナノであることだけで対応できるもの ではない。例えば,「ナノカーボン」という言葉が最初に登場 したといわれる研究プロジェクト「先進エネルギーデバイス 用ナノカーボンの基礎科学と応用」で対象とされる炭素材料 はフラーレンやナノチューブのみではない。そこでは, ナノ スケールでの構造制御が重要な問題である。例えば, エネル ギー問題との関連で天然ガス (あるいはメタンガス)さらには 水素ガスの貯蔵は重要な問題であり,そのために炭素材料が 大きな役割を果たすことが期待されている。メタンガスの貯 蔵に対しては, $2 \mathrm{~nm}$ 以下のミクロポアーが必要であり, そのよ うな細孔を大量に炭素材料中に作り出すための多くの努力が なされている。それはとりもなおさず,ナノスケールでの構 造が制御された (nano-structured) 炭素材料の製造である。水 素の貯蔵については, 水素がどのようなサイトに貯蔵される かで議論が分かれており明らかでないが，ナノサイズのサイ トが必要であり,ナノスケールでの構造制御を必要としてい ることは間違いがない。

黒鉛へのホウ素のドーピングが, リチウム二次電池の負極 性能との関連のみでなく, 種々の点で注目されている。ホウ 素は黒鉛構造中に置換固溶し得る数少ない元素の1つであり， その電子物性に対する影響も興味深いものがあり, 最近多く の研究がなされている。これもまた, 黒鉛のナノ構造の制御 にほかならない。

したがって,ここではナノスケールのサイズをもつ(nanosized) 炭素材料のみでなく,ナノ構造を制御された（nanostructured）炭素材料もあわせて,ナノカーボンと呼ぶことを 提案したい。クラシックカーボン, ニューカーボンそしてナ ノカーボンに分類される代表的な炭素材料をTable 3 にまと めた1)。

現在, 炭素材料の中の細孔は, そのサイズそれぞれに用途が あり, 前述の水素, メタンガスなどに対するミクロポアーから， ガソリン蒸気の収集のためのキャニスター用炭素材料のメソポ アー, そして重油の収着・回収を受けもつ膨張黒鉛中のマク ロポアーまで広い範囲に及んでおり, 従来の活性炭 (activated carbons)のもつイメージから離れて多孔質炭素材料 (porous carbon materials, porous carbons）と呼ぶほうが適当であろう。 
Table 3 Proposed scheme for classification of carbon materials.

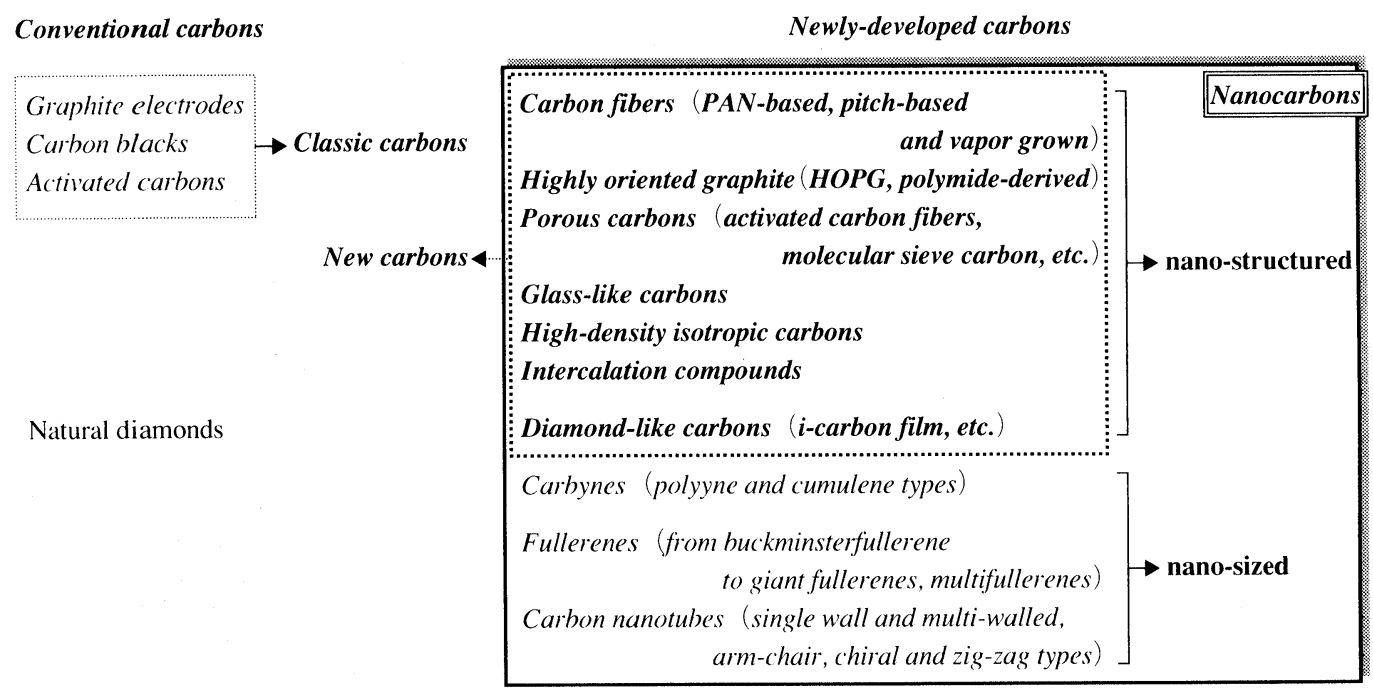

そして, その細孔構造の制御も, 活性炭での酸化反応を利用し た賦活 (activation) から, ポリマーブレンド法さらにはテムプ レート法と呼ばれる新しい方法が使われるようになっており， 多孔質炭素のいくつかはそのナノ構造制御によって作られて いる。したがって,クラシックカーボンに分類される活性炭 が,ささらに発展して二ューカーボンに分類される多孔質炭素 となり，その中のあるものはナノカーボンに分類し得るもの である。しかし，例えば膨張黒鉛のように主としてそのマク ロポアーを利用して重油の収着を行う場合にはナノ構造を制 御しているとは言えない。

\section{7. おわりに}

炭素材料の発展を3期に分けて考え, それぞれの期間で開発 された炭素材料とそれら全体としての特徵を考えるとともに, それらの炭素材料がどのように分類し, どのように呼ばれて きたかをまとめてみた。これらの考察をもとに,ナノカーボ ンには, そのサイズがナノスケールであるもの (nano-sized) のみでなく,ナノスケールでの構造を制御されている (nano- structured）炭素材料も含めるべきであることを記した。

21 世紀に我々人類が対面せざるを得ない環境そしてエネル ギ一問題の解決のために炭素材料は大きな役割が期待されて いる。その役割を果たすためにはここで定義したナノカー ボンが担うべき場面が多々生じるであろう。

\section{文 献}

1) M. Inagaki and L. R. Radovic, Carbon (in press).

2) M. Inagaki, "New Carbons-Control of Structure and Functions-," Elsevier (2000) p.229.

3) Extended Abstracts "Symposium on Carbon, Tokyo" (1964).

4) A. Oberlin, M. Endo and T. Koyama, J. Cryst. Growth, 32, (1976) 335.

5) M. Inagaki, Ed. "Introduction · Carbon Families" Agune Syoufu Sha (2001) p.204 [in Japanese].

6) E. Yasuda, TANSO 1995 [No.170] 317 [in Japanese].

7) E. Yasuda and M. Inagaki, "Carbon Alloys -Space Control and Functional Development of Carbon Materials-," Elsevier (in press).

8) T. Enoki and B. L. V. Prasad, TANSO 2001 [No. 198] 139 [in Japanese]. 